\title{
An investigation of ozone and planetary boundary layer dynamics over the complex topography of Grenoble combining measurements and modeling
}

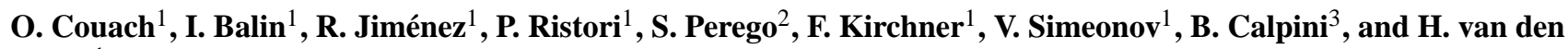 \\ Bergh $^{1}$ \\ ${ }^{1}$ Air Pollution Laboratory (LPAS), Swiss Federal Institute of Technology (EPFL) CH-1015 Lausanne, Switzerland \\ ${ }^{2}$ IBM Suisse, Altstetterstrasse 124, 8010 Zurich, Switzerland \\ ${ }^{3}$ SwissMeteo, Aerological Station, Payerne, Switzerland
}

Received: 31 July 2002 - Published in Atmos. Chem. Phys. Discuss.: 14 February 2003

Revised: 14 May 2003 - Accepted: 19 May 2003 - Published: 27 May 2003

\begin{abstract}
This paper concerns an evaluation of ozone $\left(\mathrm{O}_{3}\right)$ and planetary boundary layer (PBL) dynamics over the complex topography of the Grenoble region through a combination of measurements and mesoscale model (METPHOMOD) predictions for three days, during July 1999. The measurements of $\mathrm{O}_{3}$ and PBL structure were obtained with a Differential Absorption Lidar (DIAL) system, situated $20 \mathrm{~km}$ south of Grenoble at Vif (310 m ASL). The combined lidar observations and model calculations are in good agreement with atmospheric measurements obtained with an instrumented aircraft (METAIR). Ozone fluxes were calculated using lidar measurements of ozone vertical profiles concentrations and the horizontal wind speeds measured with a Radar Doppler wind profiler (DEGREANE. The ozone flux patterns indicate that the diurnal cycle of ozone production is controlled by local thermal winds. The convective PBL maximum height was some $2700 \mathrm{~m}$ above the land surface while the nighttime residual ozone layer was generally found between 1200 and $2200 \mathrm{~m}$. Finally we evaluate the magnitude of the ozone processes at different altitudes in order to estimate the photochemical ozone production due to the primary pollutants emissions of Grenoble city and the regional network of automobile traffic.
\end{abstract}

\section{Introduction}

The photochemical ozone production in and around large cities, a well documented phenomena (Haagen-Smit et al., 1953), often leads to ozone concentrations that exceed the limits set by the European legislation. Despite the high frequency of summer smog episodes and the ozone effects on the human health and vegetation, the details of this problem are still not well understood due to the complexity of the non-

Correspondence to: I. Balin (ioan.balin@epfl.ch) linear ozone formation process as well as to the local and regional sources and atmospheric flow patterns. Typically then the assessment and the prediction of summer ozone smog often needs to be based on a combination of measurements and mesoscale models, which in turn need to be validated during intensive field campaigns. In spite of the need of such models to assess abatement scenarios, remarkably few models are operational and further more are not often validated based on field measurements (Russel and Denis, 2000). In this context, here we present temporal ozone formation obtained from the METPHOMOD model (Perego, 1999) in conjunction with an intensive field campaign applied in the Grenoble region during July 1999.

It is well known that ozone is produced from Volatile Organic Compounds (VOC) and nitrogen oxides $\left(\mathrm{NO}_{\mathrm{x}}\right)$ emissions under strong solar radiation. Recent studies ( $\mathrm{Ba}$ and Traimany, 2001) show that the traffic in Grenoble is increasing (e.g. 7\% between 1997 and 1998) and it accounts for $57 \%$ of $\mathrm{NO}_{\mathrm{x}}$ and $37 \%$ of VOC in the total emissions budget. The Grenoble region is often subject to high ozone concentrations ( $>90 \mathrm{ppb})$ in the summertime. A pre-campaign experiment was conducted during the summer (Grenoble, 1998) in the southern region of the Grenoble valley where ozone concentrations of up to $110 \mathrm{ppb}$ were observed. In addition there was a clear influence of the valley topography on ozone formation which highlighted the need to investigate the flow dynamics (Couach et al., 1999). The Grenoble region is a deep Y shaped valley with regionally complex topography (Fig. 1). In order to understand the influence of this topography on the photochemical processes both modeling and 3D measurement approaches were simultaneously under taken during the 1999 GRENOPHOT campaign (Couach et al., 2000). Ozone and $\mathrm{NO}, \mathrm{NO}_{2}$ and $\mathrm{HCHO}$ (Jimenez et al., 2000 ) as well as meteorological variables (wind, temperature, solar radiation and relative humidity) were measured at fixed ground level stations. Different ozone vertical profiles

(C) European Geosciences Union 2003 


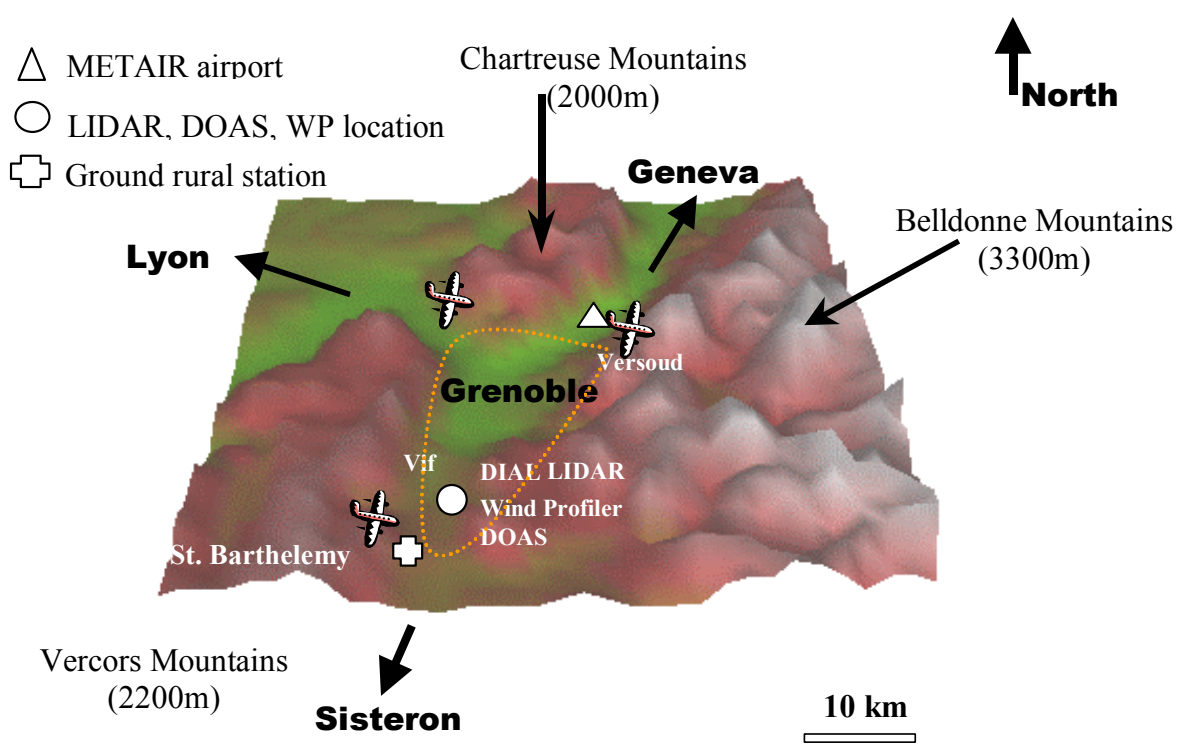

Fig. 1. Topography and locations of fixed instruments and flight path in the Grenoble modeling domain: the Belledone Mountains to the East, the Charteuse massif to the North and the Vercors to the West. Horizontal extent is $68 \times 78 \mathrm{~km}$ and the horizontal grid cell size for this domain was $2 \mathrm{~km}$.

and PBL heights measurements were taken with the EPFL ozone LIDAR- DIAL system (Simeonov et al., 1999b), an instrumented aircraft (METAIR, Neininger et al., 2001), and a wind profiler (i.e. DEGREANE, S. A., 1999).

In this paper, we present results obtained during the first Intensive Observation Period (IOP) of the summer of 1999 (25-27 July). During this observation period the synoptic weather in the French Alps was dominated by northwesterly winds on 25 July, changing to southwesterly flows on 27 July at noon (Fig. 2). The wind speed at $5 \mathrm{~km}$ altitude was approximately $16 \mathrm{~m} / \mathrm{s}$ during the 26 July decreasing to around $9 \mathrm{~m} / \mathrm{s}$ at noon on 27 July. At the end of 27 July, an atmospheric front passed through bringing thunderstorms, rain, and lower temperatures. In this paper the aircraft ozone measurements and the various meteorological measurements in the Grenoble region are first used to assess the model predictions (meteorology and chemistry) and then the validated model is used to understand the dynamics and the photochemical processes of the ozone spatial and temporal patterns in Grenoble region (Couach et al., 2002a).

\section{Field measurements}

The following field measurements obtained during GRENOPHOT 99 are used in this paper.

\subsection{Ground level measurements}

Ozone was measured at two stations at $30 \mathrm{~km}$ and respectively $20 \mathrm{~km}$ South of Grenoble city: St-Barthélémy at $620 \mathrm{~m}$ ASL and Vif at $310 \mathrm{~m}$ ASL (see Fig. 1). At St-Barthélémy the ozone was measured using a Dasibi ozone point monitor (+/- $1 \mathrm{ppb}$ precision), which is based on ozone UV absorption at $254 \mathrm{~nm}$. Ozone measurements at Vif were performed with the Differential Optical Absorption Spectroscopy (DOAS 2000 Thermo Environmental Instr.) system. The DOAS system uses the ozone UV differential absorption (267-299 nm) along a $1000 \mathrm{~m}$ integrated optical path with +/- 1 ppb precision (Jiménez et al., 2001).

\subsection{LIDAR measurements}

The LIDAR (LIght Detection And Ranging) system was collocated with the DOAS system at Vif in order to measure the vertical ozone profiles. The near ground level ozone, the first point of the vertical profile, is the ozone concentration as measured with the DOAS system. The EPFL ground based LIDAR is a mobile unit that has already been used in various European field campaigns (Calpini et al., 1997). This LIDAR system (schematic layout in Fig. 3) is an ozone DIAL (DIfferential Absorption LIDAR) system based on the ozone differential absorption at two wavelengths $\lambda_{\text {on }}=289 \mathrm{~nm}$ (more absorbed by ozone: $\sigma_{\mathrm{O}_{3}}=$ $1.5 \mathrm{E}-18 \mathrm{~cm}^{2}$ ) and $\lambda_{o f f}=299 \mathrm{~nm}$ (less absorbed by ozone: $\left.\sigma_{\mathrm{O}_{3}}=4.1 \mathrm{E}-19 \mathrm{~cm}^{2}\right)$. Based on a Nd:YAG laser $(1064 \mathrm{~nm})$, two quadrupled crystals (for obtaining $266 \mathrm{~nm}$ ) and two Raman high pressure D2 and $\mathrm{H}_{2}$ cells, the 289 and $299 \mathrm{~nm}$ beams are emitted sequentially in the atmosphere as "on" and "off" wavelengths, with a repetition rate of $10 \mathrm{~Hz}$. The average of 4000 shots (corresponding to 6 min $40 \mathrm{~s}$ ) was used to obtain each $\mathrm{O}_{3}$ profile. The reception part consists of a $20 \mathrm{~cm}$ Newtonian telescope for short-range $(0.15-1 \mathrm{~km})$ 
(a)
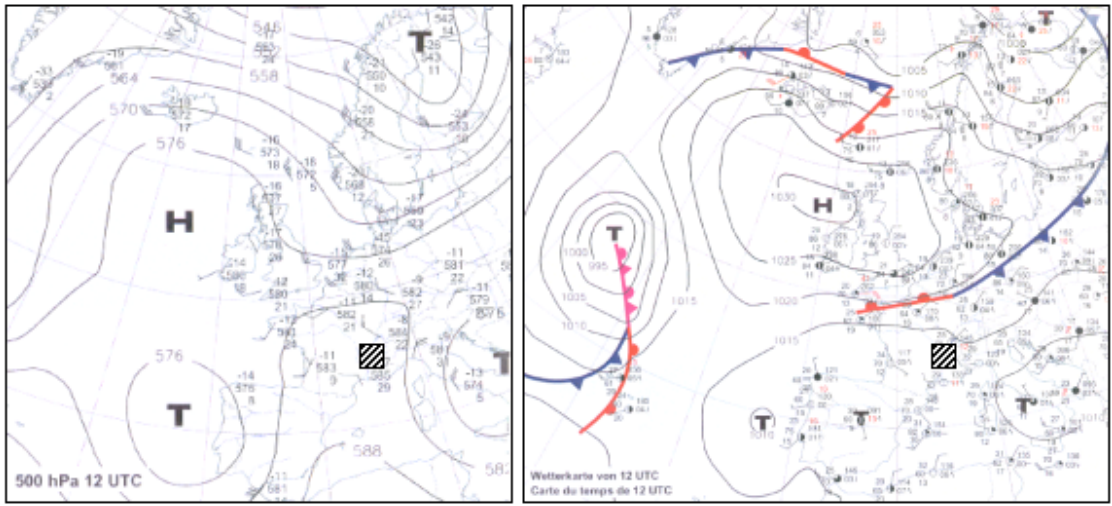

(b)
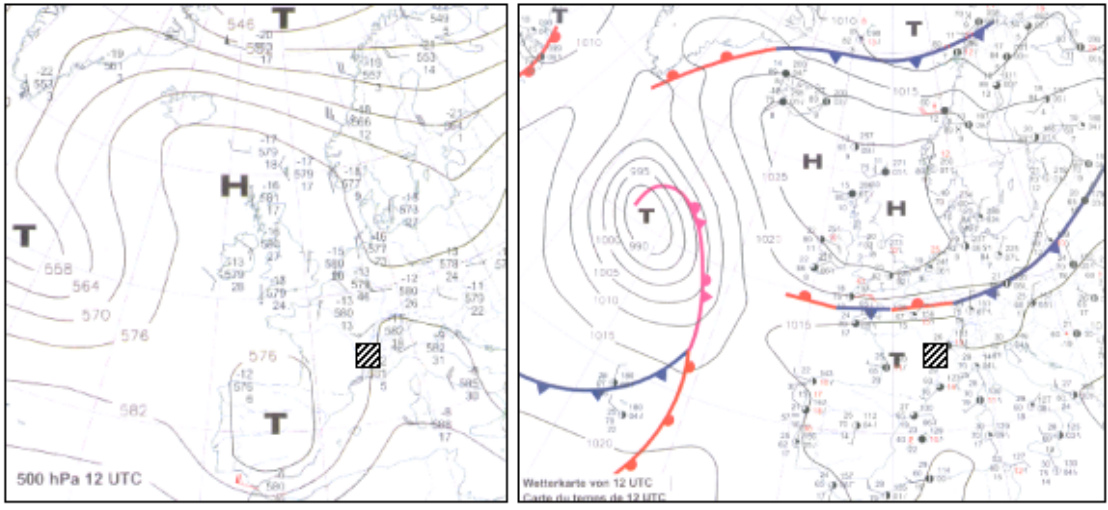

Modeling domain

Fig. 2. Geopotential heights (gpdam) of the $500 \mathrm{hPa}$ layer, 12:00 UTC (a) surface air pressure 1999, 12:00 UTC (b) on 26 and 27 July 1999.

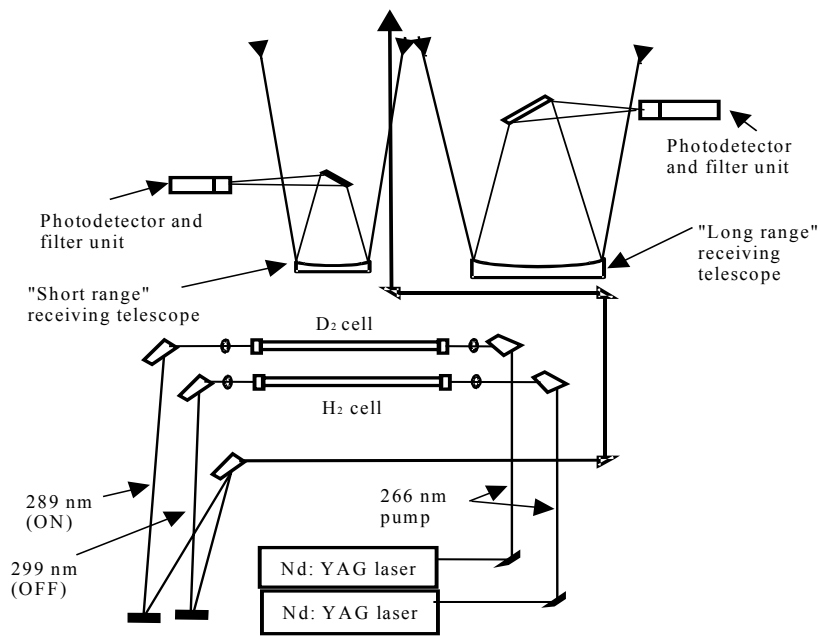

Fig. 3. Ozone DIAL LIDAR layout (1998 LPAS-EPFL system configuration). The LIDAR ozone measurements are averaged over 30 min with $250 \mathrm{~m}$ vertical resolution. The precision of the ozone lidar measurements is decreasing from $5 \%$ at $500 \mathrm{~m}$ to $20 \%$ at $3500 \mathrm{~m}$ above the LIDAR site. detection and a $60 \mathrm{~cm}$ Cassegrain telescope for long-range measurements $(0.8-3 \mathrm{~km})$. Ultra compact photomultiplier tubes (Hamamatsu model 5783-06) in analogue detection mode (Simeonov et al., 1999a) are used with a 12 bit $20 \mathrm{MHz}$ ADC, (LICEL transient recorder) unit (i.e. $7.5 \mathrm{~m}$ vertical resolution). Daytime operation is possible by using two solar blind filters and one holographic band pass filter for each telescope (Simeonov et al., 1999b). Due to the differential calculation the retrieval of the ozone vertical profile does not require external calibration. At the same time as the ozone measurements are obtained the total backscattered light at $\lambda_{\text {off }}=299 \mathrm{~nm}$ by the aerosols (Mie aerosols scattering) and by the nitrogen and oxygen molecules (Rayleigh molecular scattering) is collected. The total (Mie + Rayleigh) over molecular (Rayleigh) ratio allows the estimation of the evolution of PBL height, the structure of the residual layer and the mixed layer and the relative aerosol concentrations. The PBL height was estimated as the altitude corresponding to the largest decreasing step on the backscatter profile using $299 \mathrm{~nm}$. The exact PBL height was taken to be the inflexion point of the 2 nd derivative of the ratio of total/molecular. 
(a)

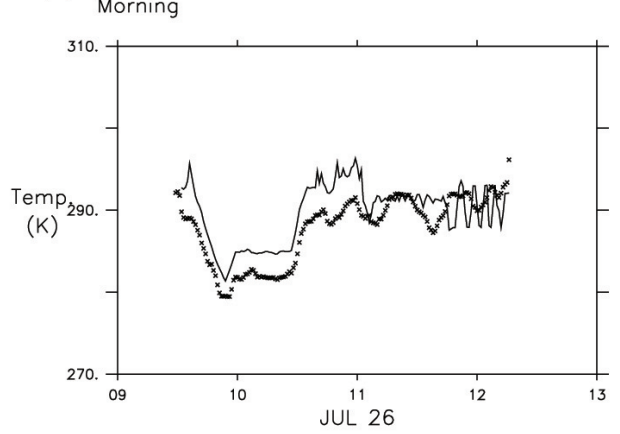

(c)

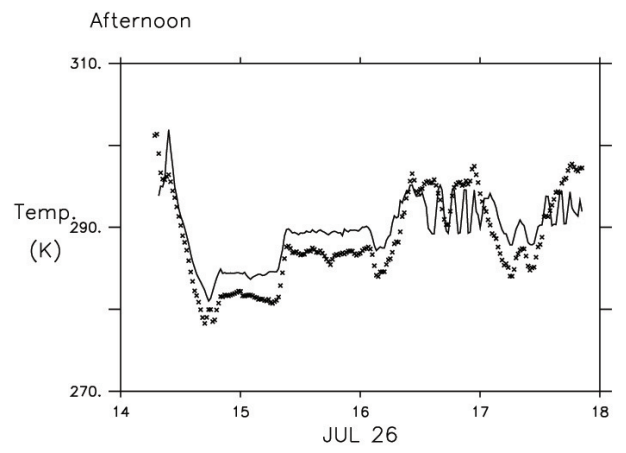

(b)

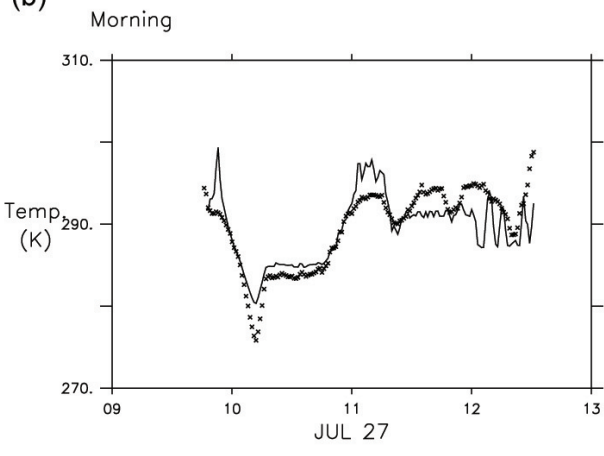

$x \times x$ fly

(d)

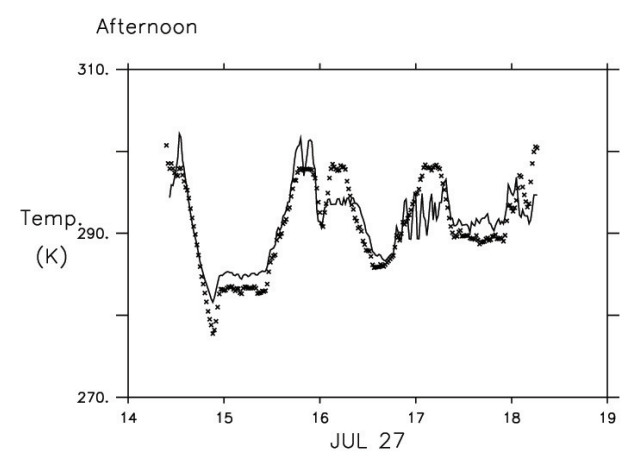

Fig. 4. Temperatures comparison of aircraft measurements (see typical flight in Fig. 1) with model calculations during 26 and 27 July aircraft flights: morning (a)(b) and afternoon (c)(d).

\subsection{Wind profiler measurements}

At Vif, next to the LIDAR system, a RADAR Doppler wind profiler system (from DEGREANE: Model PCL1300, Frequency emission: $1238 \mathrm{MHz}$ ) was used to obtain three dimensional wind speed measurements up to about $3000 \mathrm{~m}$ with a vertical resolution of $\sim 100 \mathrm{~m}$ and with a precision of $1 \mathrm{~m} / \mathrm{s}$ for the wind speed and $10^{\circ}$ for the wind direction (Ruffieux, 1999). Using the wind measurements above Vif we estimated the horizontal ozone "fluxes" $\overrightarrow{\mathrm{O}_{3}}(\mathrm{z})(\mathrm{ppb} \mathrm{km} / \mathrm{h})$ by multiplying the 30 minute LIDAR ozone profiles $\mathrm{O}_{3}(\mathrm{z})$ (ppb) with the horizontal wind velocity $\overrightarrow{\mathrm{u}}(\mathrm{z})(\mathrm{km} / \mathrm{h})$ at different altitudes (Quaglia et al., 1999).

\subsection{Aircraft measurements}

The instrumented Swiss aircraft METAIR took part in the GRENOPHOT campaign on 26 and 27 July 1999. There was 1 flight in the morning and 1 flight in the afternoon. The aircraft typical path (see Fig. 1) was done at various altitudes in the $\mathrm{Y}$ valleys. The air pollutants concentrations $\left(\mathrm{O}_{3}, \mathrm{NO}_{2}\right.$,
$\mathrm{NO}_{\mathrm{x}}$, aerosols $>0.3 \mu \mathrm{m}$ and water vapor mixing ratio) and meteorological point measurements (wind, pressure, temperature, relative humidity) were obtained using standard equipment installed in the aircraft (Neininger et al., 2001).

\section{Modeling approach}

The air quality model METeorological PHOtochemistry MODel (METPHOMOD) is used here to investigate the spatial and temporal patterns of air pollution during GRENOPHOT 1999. This model has both a meteorological module, which calculates wind, potential temperature and humidity fields, as well as an atmospheric chemistry module to compute transport and chemical reactions (Perego, 1999). The chemical module is based on the Regional Atmospheric Chemical Mechanism (RACM), a lumped species mechanism (Stockwell et al., 1997).

Two different modeling domains were used. The model was applied first on a large domain $(240 \mathrm{~km}$ horizontal side) composed of $40 \times 40$ cells of $6 \times 6 \mathrm{~km}$. This field covers 
(a)

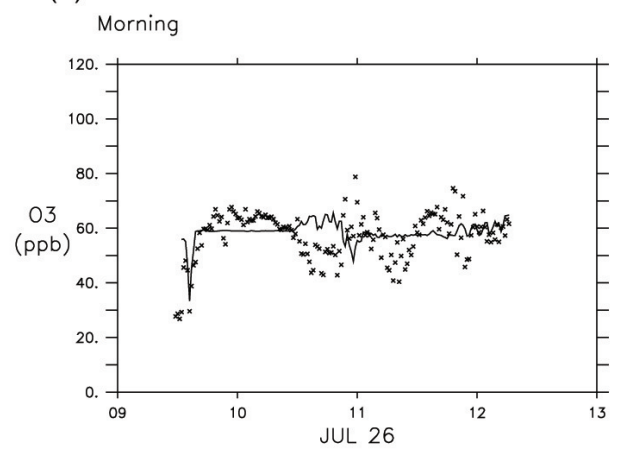

(c)

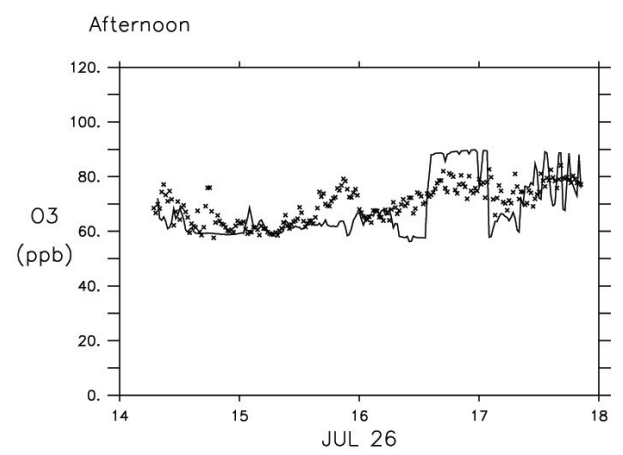

(b)
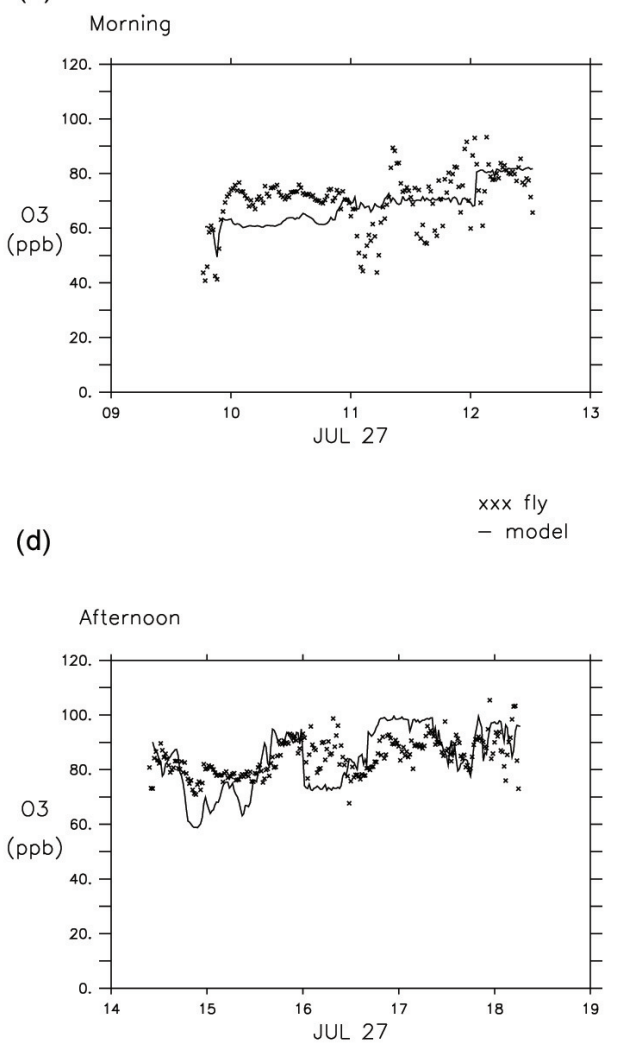

Fig. 5. Ozone comparison of aircraft measurements (see typical flight in Fig. 1) with model calculations during aircraft flights on 26 and 27 July 1999: morning (a)(b) and afternoon (c)(d).

the Rhône-Alpes region and its main cities. The results on the large domain are used to specify the boundary conditions for a higher resolution domain through one-way nesting. This smaller horizontal domain covers a rectangle of $68 \times 78 \mathrm{~km}$, centered on Grenoble and aligned north-south, with $34 \times 39$ cells of $2 \times 2 \mathrm{~km}$. In the vertical direction a system of Cartesian coordinates, identical for both the large and the small domain, is used with 26 levels with increasing heights from $50 \mathrm{~m}$ (ground) to $1000 \mathrm{~m}$ at $8000 \mathrm{~m}$ at the top of the simulated domain. The meteorological boundary conditions (wind direction and speed, temperature, air humidity and the upper layer pressure) were obtained from Swiss Meteorological Institute synoptic-scale model (Majewski, 1991).

The emission inventory distinguishes between surface (9 sectors), linear (motorways and highways) and point emissions. These emissions are also space and time-resolved (distinction is made between weekdays and Sunday). The inventory includes emissions of $\mathrm{NO}_{\mathrm{x}}, \mathrm{CO}, \mathrm{CH}_{4}$, and 23 non-methane hydrocarbon species (NMHC). These emissions are lumped into 32 VOC classes as required by RACM mechanism. The biogenic emissions are estimated based on the surface emission inventory of the forest landscape. Three-dimensional photochemical model simulations were performed for the 3-day IOP of 25 July to 27 July 1999. The meteorological and chemical model outputs were compared with ground and three-dimensional measurements performed during the IOP (25-27 July) when the ozone concentrations reached up to $95 \mathrm{ppb}$ (Couach et al., 2002a). The Figs. 4 and 5 show the temperature and ozone model and the aircraft measurements comparison for 4 flights ( $\sim 3$ hours per flight) in morning and afternoon over the Grenoble area at various altitudes (typical flight path in Fig. 1). In Fig. 6 the vertical ozone measured by LIDAR and aircraft as well as the output of model are compared above Vif at 14:00 LT on 26 July. There is generally good agreement between the model calculations and the lidar measurements as well as with the standard instrumented aircraft measurements. Based on these results, we believe it is appropriate to combine the LIDAR measurements with the model outputs for the following analysis and interpretation. 


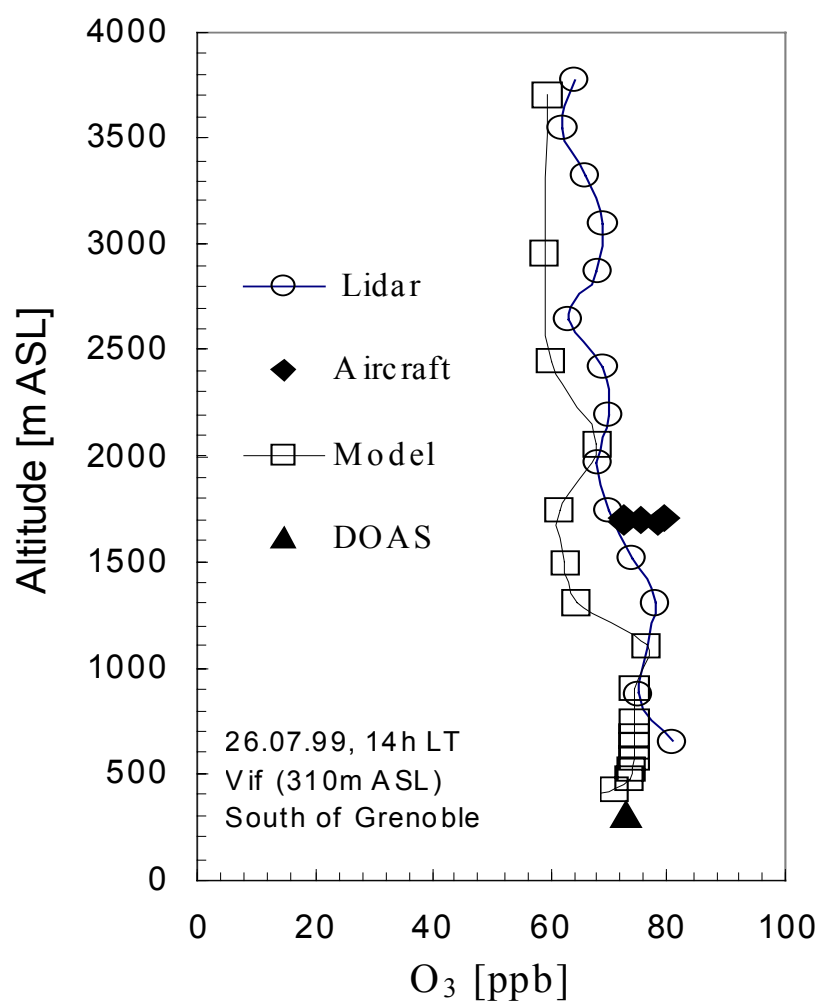

Fig. 6. LIDAR, DOAS, aircraft and model ozone measurements: Vif, 14:00 LT, on 26 July The accuracy of ozone LIDAR retrieval is always less than $10 \%$ when compared with the standard ozone measurements of the instrumented aircraft. The simulated ozone by model is in good agreement both with the aircraft and LIDAR measurements.

\section{Results and discussions}

Based on the initial satisfactory comparisons of model output with LIDAR and aircraft we now consider the three days of continuous measurements of LIDAR and wind profiler above Vif, the aircraft flights as well as the METPHOMOD model results for the July IOP. The estimation of the ozone plume dynamics and the evolution of the PBL height and its sublayers structure are now discussed in detail.

4.1 Time evolution of the PBL structure and of the vertical ozone distribution

In Fig. 7, we present the three days of continuous measurements as follows: (a) wind direction, (b) wind speed, (c) LIDAR backscatter ratio (total/molecular) and (d) ozone concentration as measured by the ozone DIAL LIDAR up to $2900 \mathrm{~m}$ above Vif. The wind patterns are clearly dominated by the diurnal thermal regime. The daytime winds in the valley were typically from 7 to $10 \mathrm{~m} / \mathrm{s}$ northerly wind regime which developed up to $1800 \mathrm{~m}$ between 8:00-9:00 LT (local time) and 19:00-20:00 LT, while the night-time winds are rather weak, $1-2 \mathrm{~m} / \mathrm{s}$, blowing from the south. Between
$1800 \mathrm{~m}$ up to $2900 \mathrm{~m}$ we observe a low wind speed $(1-2 \mathrm{~m} / \mathrm{s})$ regime from the southwest which increased on 27 July up to $10 \mathrm{~m} / \mathrm{s}$ (see Figs. 7a and b). Above these various layers, the synoptic wind is northerly on 25 and 26 July, changing to the southwest on 27 July (see Fig. 2). Also on 27 July, in spite of the strong southwesterly wind, the usual northerly thermal wind developed near the land surface at sunrise and increased slowly reaching $1800-2000 \mathrm{~m}$ at 18:00 LT.

The LIDAR backscatter ratio (total/molecular) at $299 \mathrm{~nm}$ is proportional to the aerosol load which we consider a good tracer for estimating the time evolution and the structure of the PBL ([Couach et al., 2002a; Menut et al., 1999; Parlange et al., 1995]). In Fig. 7c, we show the backscatter ratio (total/molecular) at $299 \mathrm{~nm}$. In the same figure the two white stars correspond to the PBL height as obtain considering both water vapor and $\mathrm{PM}_{10}$ aircraft measurements. The black line is the iso-contour at 1.2 backscatter ratio (i.e. $20 \%$ of Rayleigh sky backscatter) delimitating the maximum PBL height. The green iso-contour line at 1.3-backscatter ratio value (i.e. $30 \%$ of Rayleigh sky backscatter) is determined based on the aircraft PBL estimation. The average rate of PBL growth (dh/dt) is 150 to $200 \mathrm{~m} / \mathrm{h}$. The aerosol backscatter allows the identification of different layers in the structure of the PBL: the surface layer (SL), the mixed layer (ML) and the aerosol accumulation layer (AL). The AL is located between 1600 and $2900 \mathrm{~m}$ on average for 26 and 27 July with regular convection-advection exchanges with the SL. Strong advection occurs on the 27 July between 3:00 and 8:00 LT in the morning which is followed later by thermal convection.

The PBL height over the Grenoble region is high with maximum values reaching $2700 \mathrm{~m}$ above the land surface in daytime (Prévôt et al., 2000; Wotawa and Kromp-Koft, 1999). The daily evolution of the PBL and its sub-layers structure over Vif ( $310 \mathrm{~m}$ ASL), as derived from the LIDAR data set and validated by aircraft, is also supported by the time evolution of the potential temperature profiles of the model at Vif (Fig. 8). In the Figs. 8a and b the model derived potential temperatures profiles are shown at night while the Figs. 8c and d present the afternoon profiles on 26 and 27 July. One can observe that the low surface inversion (night PBL collapse) while the top of convective layer is located around $2500 \mathrm{~m}$ ASL. On 26 July at 14:00 LT note that the capping inversion is at $\sim 1500 \mathrm{~m}$ ASL and it is less pronounced on 27 July. Later in the afternoon, the air is well mixed and there is no observable inversion up to $2500 \mathrm{~m}$ ASL.

The vertical ozone distribution derived from the ozone DIAL measurements above Vif is strongly correlated and influenced by the diurnally-varying regime and the PBL structure (Beyrich et al., 1996; Mckendry et al., 1997). The diurnal cycle of the ozone formation, the high mixed ozone layer (2500-2700 m ASL) during the day, the strong ozone titration by $\mathrm{NO}$ after midnight, particularly in the morning, and the formation of a nighttime residual layer between 1400 and $2500 \mathrm{~m}$ ASL are all clearly observable (see Fig. 7d). The 
(a) Wind Direction

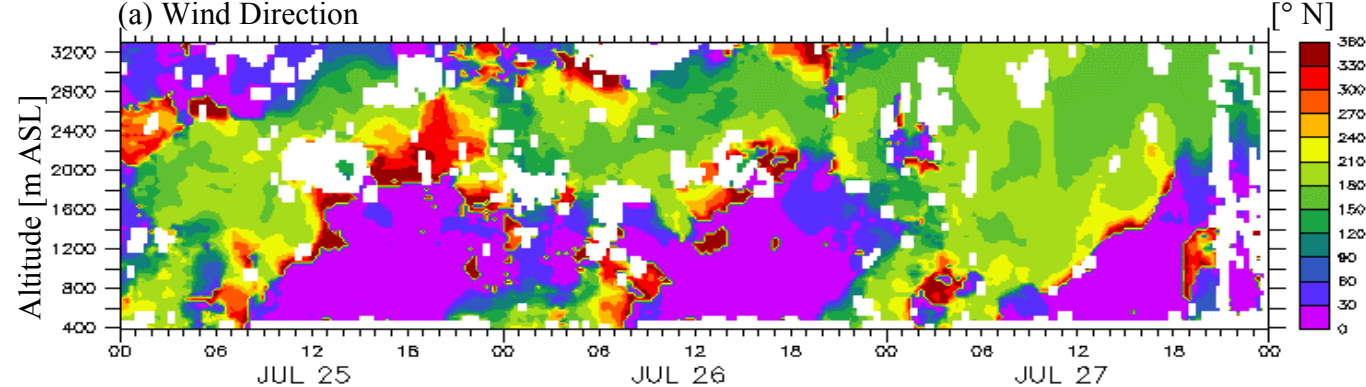

(b) Wind Speed

$[\mathrm{m} / \mathrm{s}]$

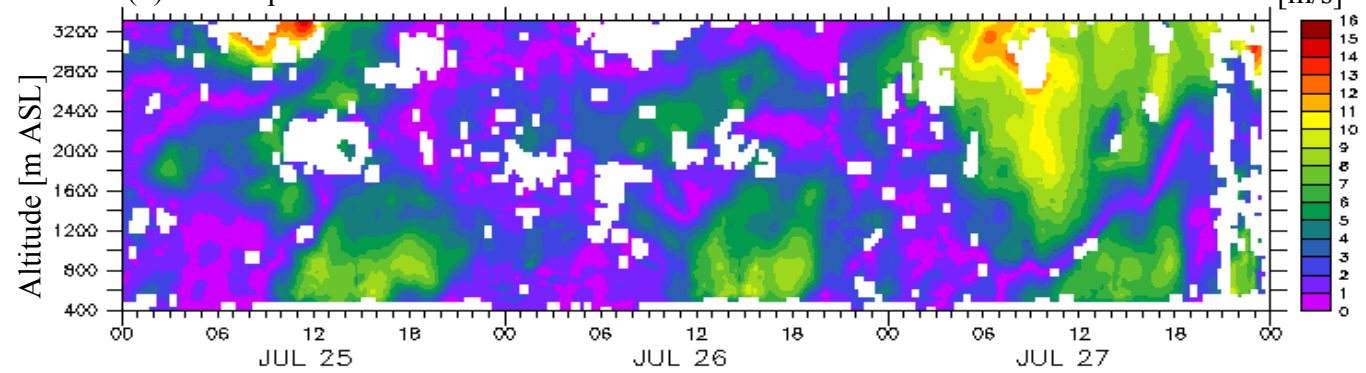

(c) Lidar Backscatter

$\approx$ Aircraft PBL

[n.u]

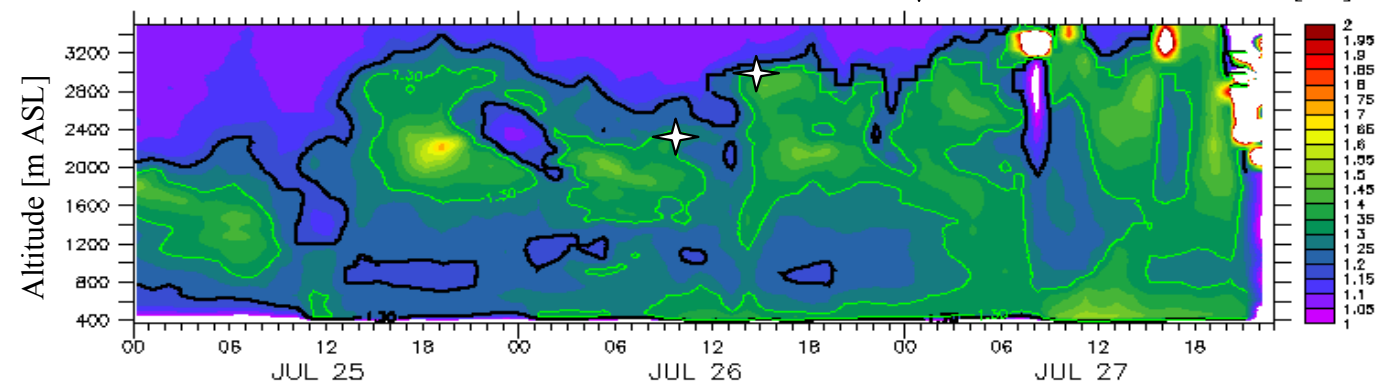

(d) Lidar Dial Ozone

[ppb]

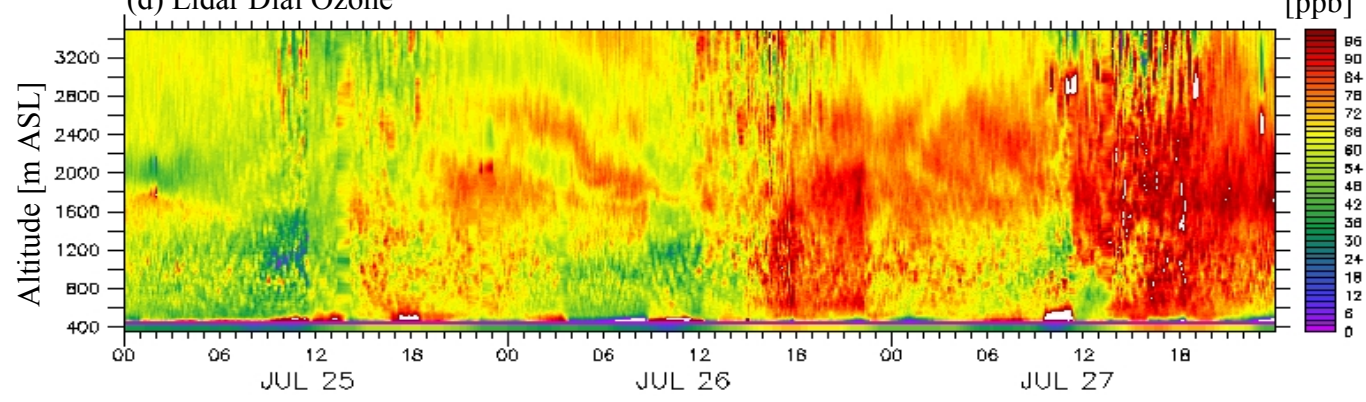

Fig. 7. Three days of wind (a) speed and (b) direction, (c) backscatter ratio at $299 \mathrm{~nm}$ and (d) ozone concentration above Vif. The thermal wind regimes are clearly seen in (a) and (b). The two stars in (c) are corresponding to the evaluation of the PBL height from the aircraft aerosols and water vapor measurements. The residual layer as well as the daily variation of the ozone concentration above Vif is presented in (d).

maximum observed ozone concentration at ground level is $85 \mathrm{ppb}$ while in the residual layer it reached up to $70 \mathrm{ppb}$. In fact the maximum ozone concentration is reached above the surface layer (i.e. St. Barthélémy at $620 \mathrm{~m} \mathrm{ASL}$ ) and is around $100 \mathrm{ppb}$ in the late afternoon of 27 July (Couach et al., 2002b). Thus, based on the LIDAR data together with ground level and wind profiler measurements, we are able to reconstruct the typical ozone vertical distribution and its time evolution in the semi-urban area at south of Grenoble. 


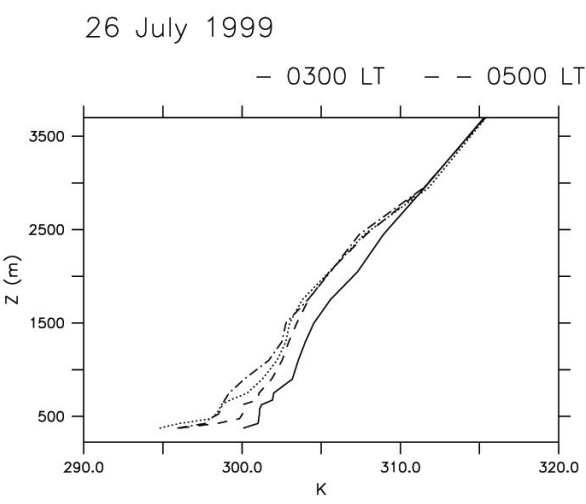

Potential temp. (k)

(a)

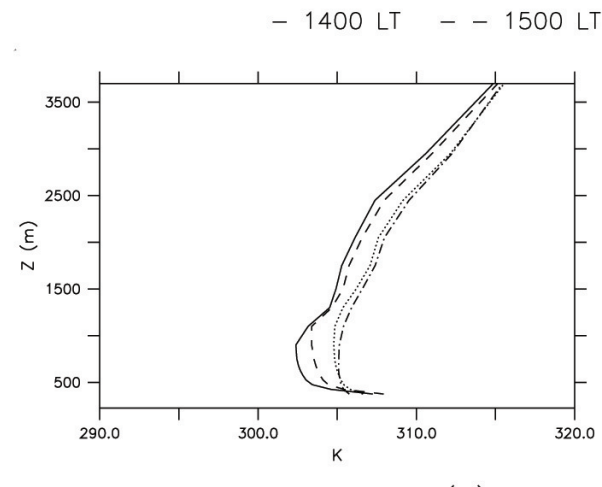

Potential temp. (k)

(c)
27 July 1999

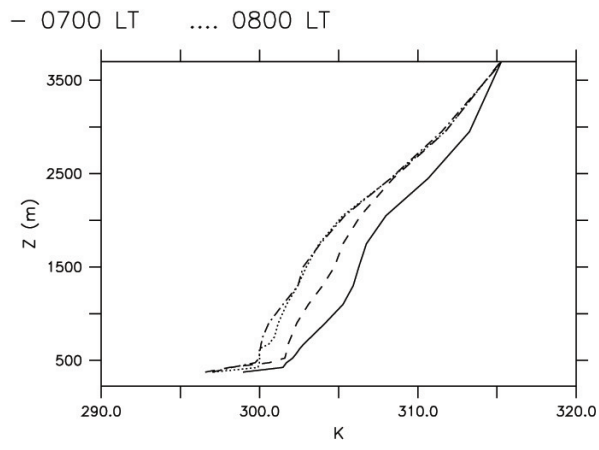

Potential temp. (k)

(b)

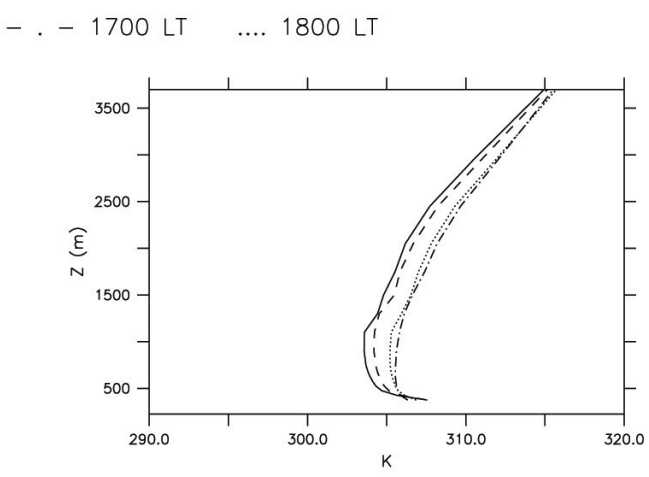

Potential temp. (k)

(d)

Fig. 8. Model calculations of virtual potential temperature profiles at Vif: (a) morning 03:00, 05:00, 07:00, 08:00 LT and (b) afternoon 14:00, 15:00, 17:00, 18:00 LT on 26 and 27 July, respectively.

\subsection{Ozone fluxes and ozone plume development}

The vertical ozone profile from LIDAR together with the wind profiler measurements provides the vertical distribution of the horizontal ozone fluxes. Four different times were chosen for presenting this vertical distribution of the horizontal ozone fluxes (see Fig. 9). In Figs. 9a and b the morning (7:15 LT) and evening (18:15 LT) ozone fluxes are presented under a typical anticyclone regime (26 July) while in the Figs. $9 \mathrm{c}$ and $\mathrm{d}$ the morning (7:15 LT) and evening (18:45 LT) ozone fluxes for 27 July are presented for a day with a transient regime. For both days the LIDAR ozone profiles converge, above $3000 \mathrm{~m}$ ASL, to a common value (free troposphere ozone value) $\sim 60 \mathrm{ppb}$ while below the profiles are different. At ground level the difference between the morning profile (reference ozone) and the late afternoon (photochemical ozone plume) is about $50 \mathrm{ppb}$ for both days. With altitude, the differences in ozone are strongly influenced by the presence of the residual layer between 1400 and $2500 \mathrm{~m}$ ASL. The shape of the vertical profiles just above the ground is determined mainly by the dry deposition (afternoon) and
NO titration (morning). The amount of the ozone removed by dry deposition, estimated from the afternoon profile as the difference between the DOAS ground ozone concentration and the first LIDAR measurement point at $\sim 500 \mathrm{~m}$ ASL ( $200 \mathrm{~m}$ above the ground) is about $10 \mathrm{ppb}$ both for 26 and 27 July. The NO titration and the dry deposition can be evaluated from the morning profile by taking the difference between the LIDAR ozone at $1250 \mathrm{~m}$ ASL for 26 July $(1500 \mathrm{~m}$ ASL for 27 July) and the DOAS ground measurement. These values are around $30 \mathrm{ppb}$ for 26 July and $40 \mathrm{ppb}$ for 27 July.

The ozone fluxes have a vertical stratification:

1. in the morning we observe a slow south flux decreasing with the altitude up to $2500 \mathrm{~m}$ ASL and above a north synoptic flux for 26 July while on 27 July there was observable only a strong south flux which increased with the altitude,

2. in the afternoon we saw clearly the typical thermal north flux in both cases up to $2000 \mathrm{~m}$ ASL with a horizontal flux of 1000-2000 (ppb km/h) above Vif. 

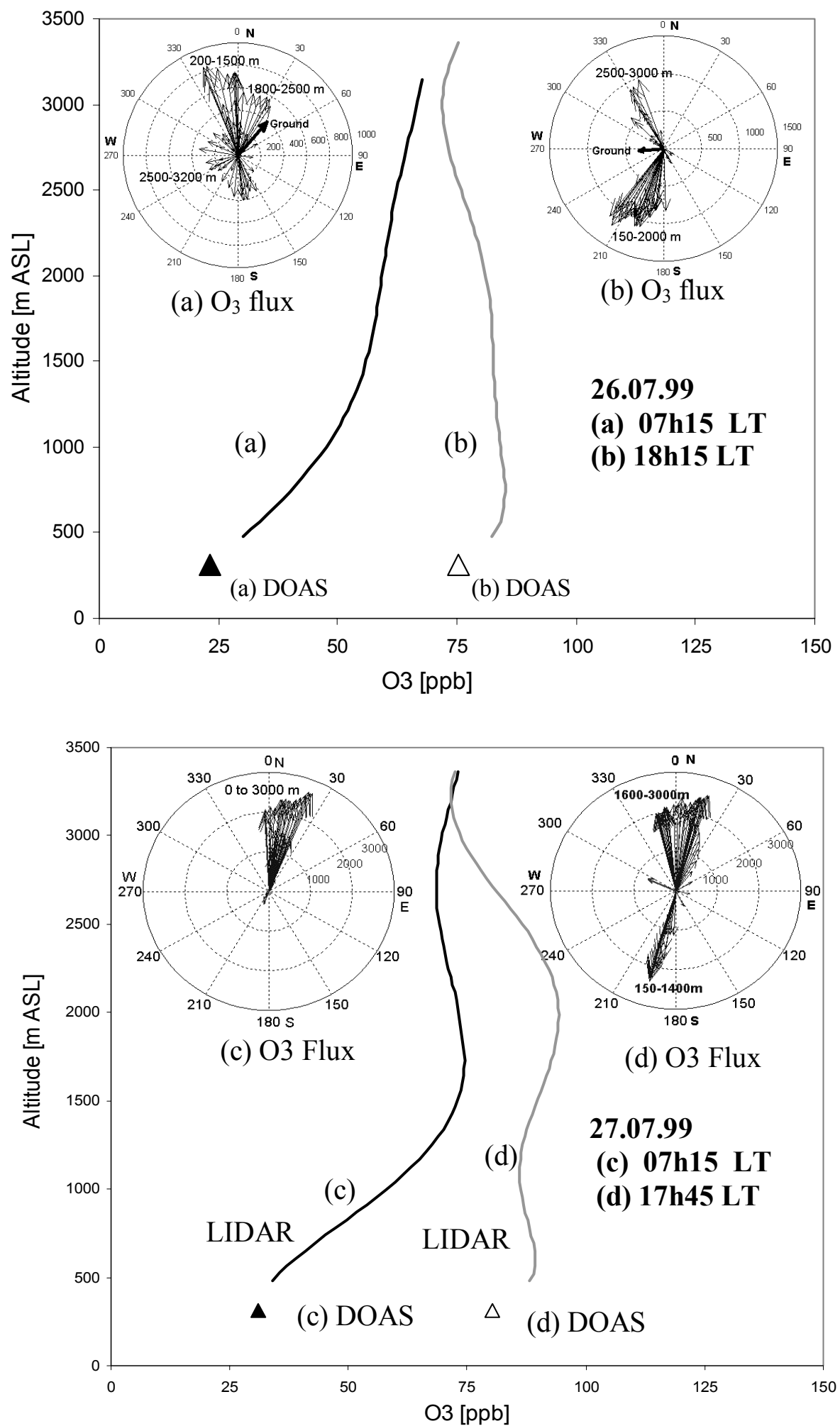

Fig. 9. Ozone profiles (a) morning and (b) afternoon, on 26 and 27 July 1999. The two flux roses are the corresponding horizontal ozone fluxes. 

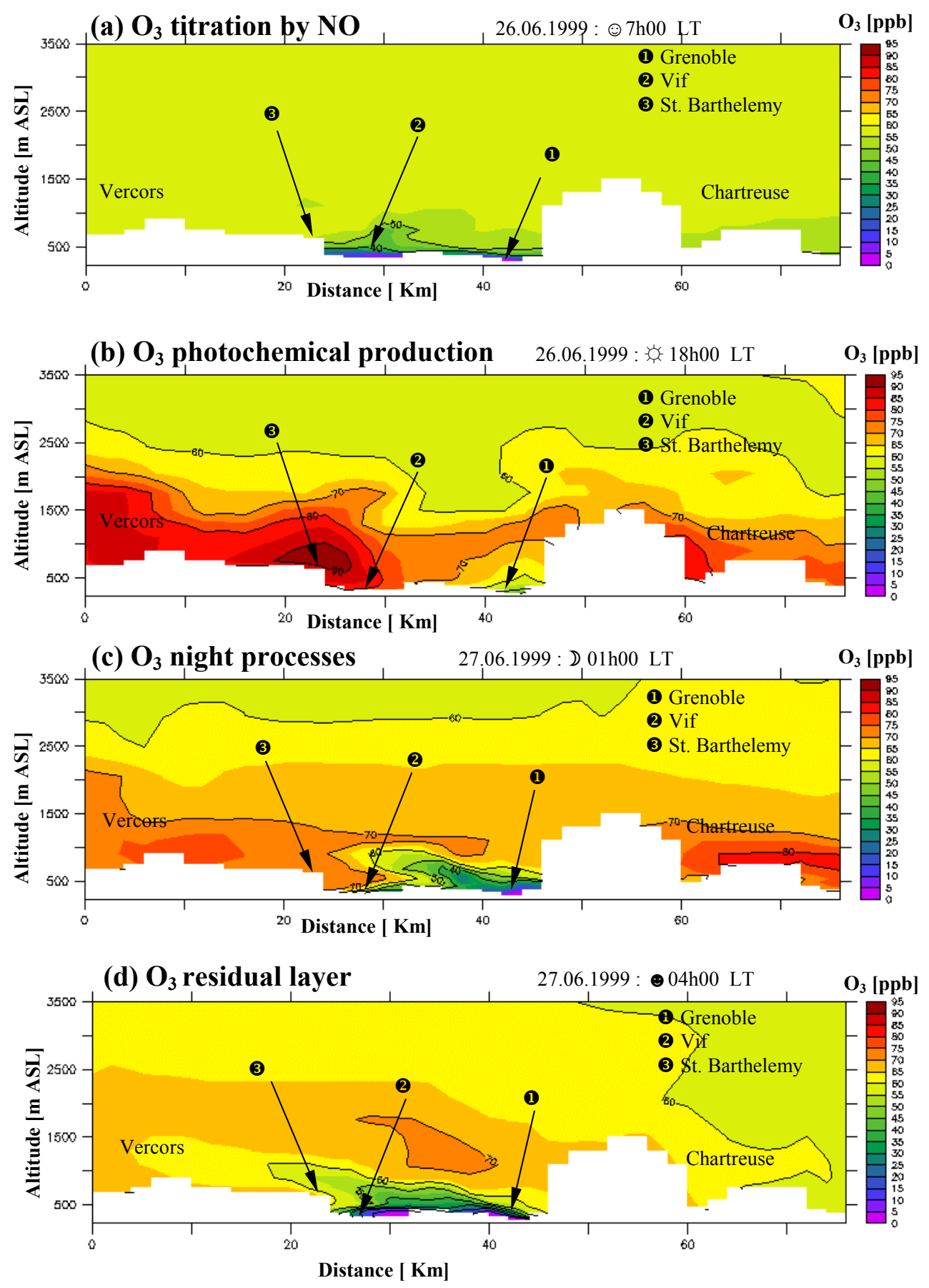

Fig. 10. Simulated ozone dynamics in a south to north (Vif - Grenoble) $50 \mathrm{~km}$ transect from the ground to $3500 \mathrm{~m}$ ASL on the vertical dimension. The ozone NO titration in the morning (a), the ozone photochemical production (b), the night ozone processes (c) and the ozone residual layer formation $(\mathbf{d})$ are represented here.

In order to visualize the development of the ozone plume over semi-urban region at south of Grenoble (e.g. Vif) we present the simulated time evolution of ozone in a south to north vertical cross-section (St-Barthélémy-Vif-Grenoble city) from the ground up to $3500 \mathrm{~m}$ ASL (see Fig. 10). On
26 July (see Fig. 10a) we note the morning ozone titration by NO in the urban (i.e. Grenoble) and suburban (e.g. Vif) areas and the background ozone concentration level of $\sim 60 \mathrm{ppb}$. In the late afternoon (see Fig. 10b) the ozone plume has moved to the south reaching concentrations of $95 \mathrm{ppb}$ (measured at 


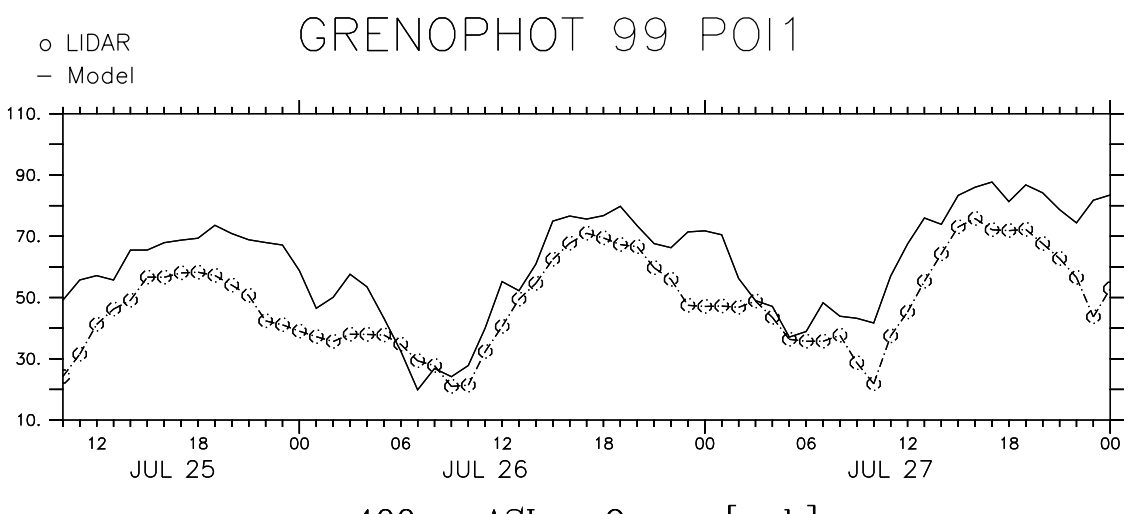

$400 \mathrm{~m} \mathrm{ASL}$ - Ozone $[\mathrm{ppb}]$
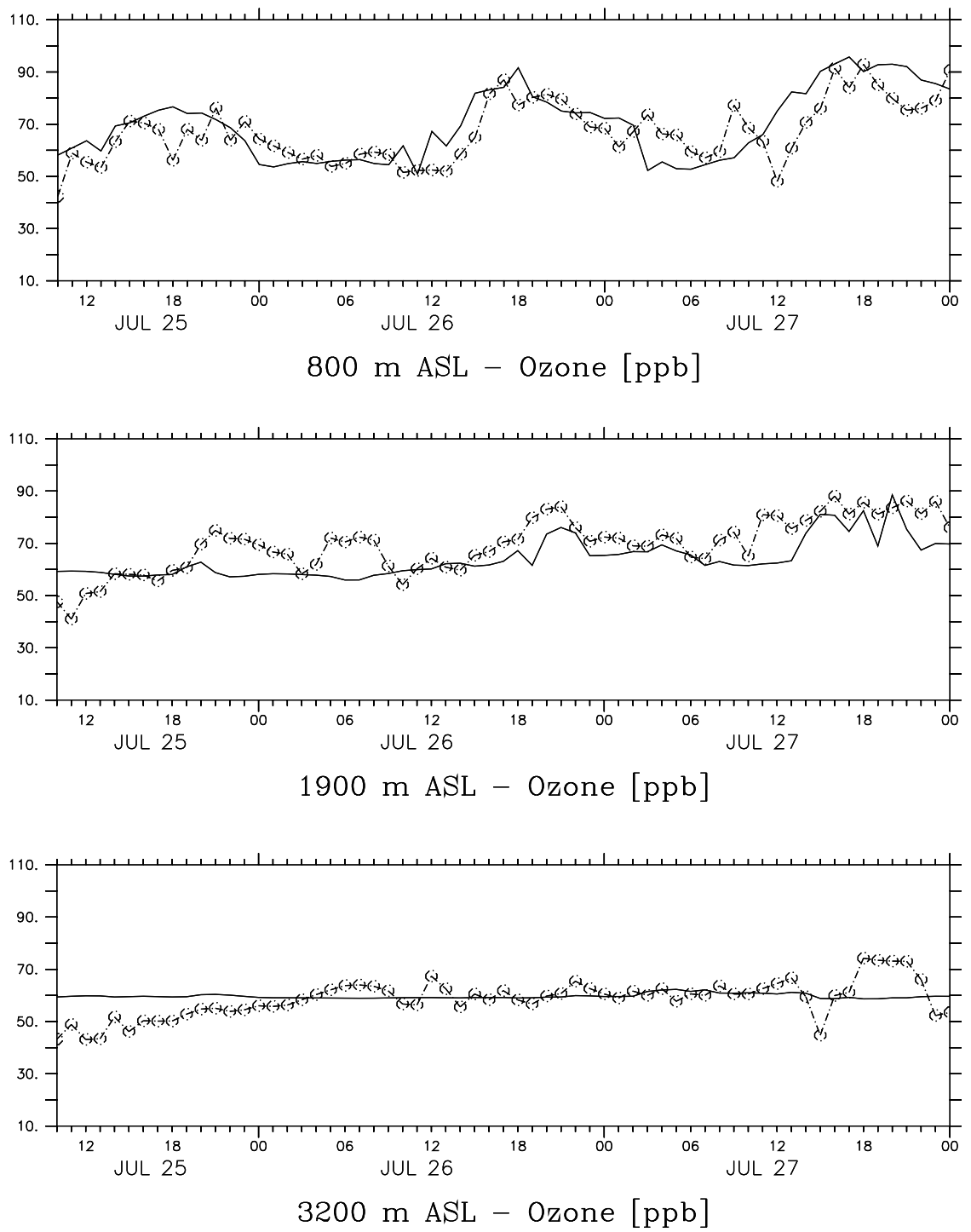

Fig. 11. Ozone vertical time evolution measured by LIDAR and simulated at different altitudes (ASL). For the ground level, the DOAS measurement was taken into account. On notice a good agreement between the model ozone calculation and the ozone concentrations measured with the LIDAR during the three days at different altitudes. 

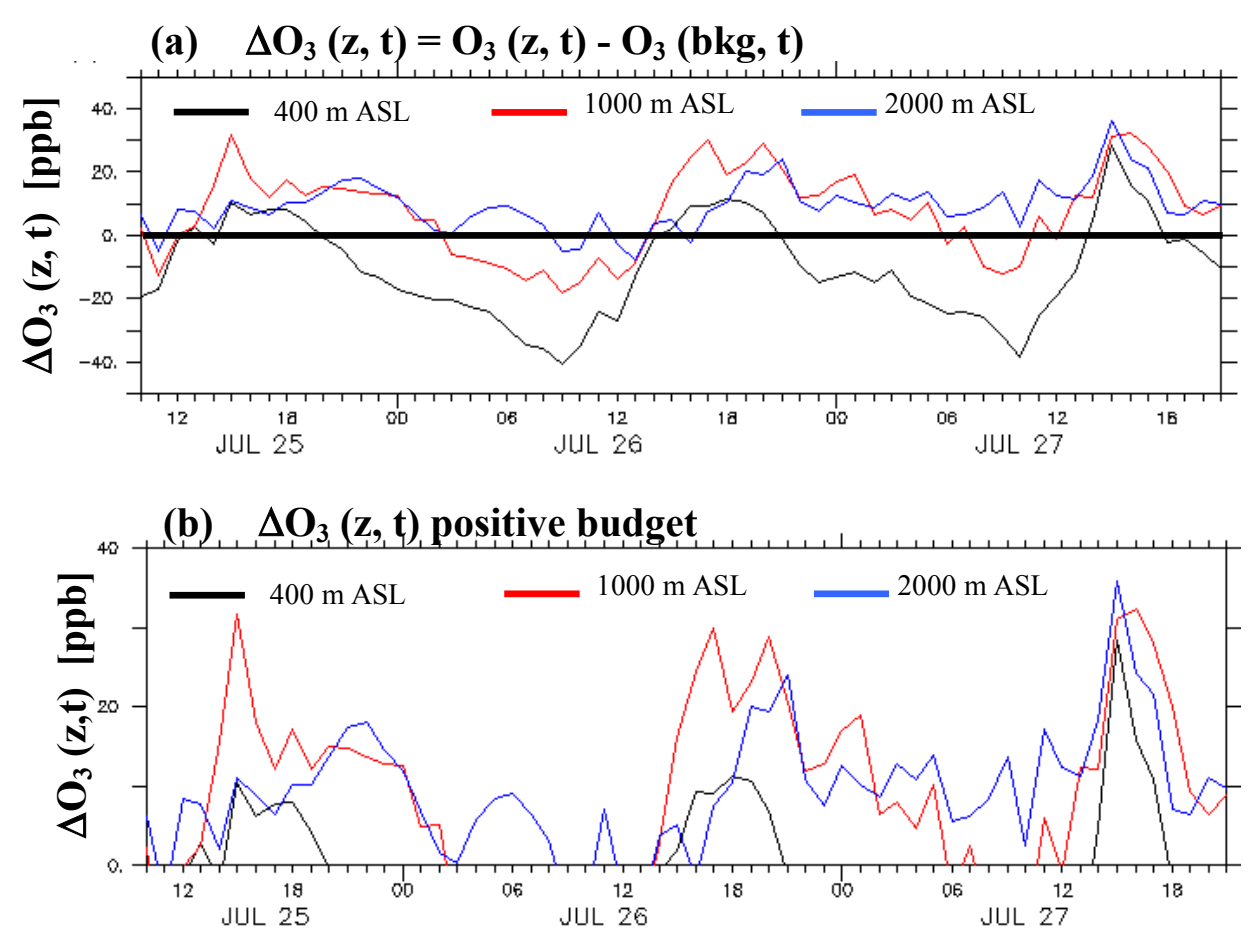

Fig. 12. Differential ozone $\left(\Delta \mathrm{O}_{3}\right)$ relative to the ozone background (free troposphere ozone) at different altitudes (i.e. ground, 800 , 1500, $2500 \mathrm{~m}$ ASL). The ozone "sinks" as well as the ozone "sources" are illustrated in (a). The positive budget (i.e. sources) is zoomed in (b) to better identify different layers contributions at the ozone production.

St-Barthélémy) at $620 \mathrm{~m}$ ASL. Interestingly, the maximum concentrations are not produced in Grenoble city or at ground level (Vif) but at higher altitudes, up to 1500-2000 m ASL, over the south rural area. After midnight, as a consequence of the absence of the photochemical processes we can observe not only the beginning of the NO titration and the dry deposition processes but also the formation of the ozone residual layer. The southern extent of the ozone residual layer contained up to $70 \mathrm{ppb}$ ozone between 1300 and $2300 \mathrm{~m}$ above the ground (Neu et al., 1994) while below the residual layer near the ground there is a strong NO titration (see Fig. 10d). The modeling calculations over the whole domain of Grenoble are not only reproducing the ozone plume dynamics but are in agreement with the measued residual layer behavior and the ozone concentrations above Vif.

\subsection{Estimation of the relative intensity of the related ozone processes}

In order to evaluate the magnitude of the photochemical processes (i.e. regional ozone photochemical potential) on the Grenoble southern semi-urban and rural areas, we treat the lidar measurements of the free troposphere ozone as the ozone background level $\mathrm{O}_{3}(\mathrm{bkg})$. Then we subtract this independent of the regional local photochemistry ozone reference value from the ozone concentrations at different altitudes: delta ozone $\Delta \mathrm{O}_{3}(\mathrm{z}, \mathrm{t})=\mathrm{O}_{3}(\mathrm{z}, \mathrm{t})-\mathrm{O}_{3}(\mathrm{bkg}, \mathrm{t})$ and we analyzed $\Delta \mathrm{O}_{3}$ during the three days time evolution. To estimate the ozone background, we consider the simulated and LIDAR measured ozone at different altitudes (A) $400 \mathrm{~m}$ ASL, (B) $800 \mathrm{~m}$ ASL, (C) $1900 \mathrm{~m}$ ASL and (D) $3200 \mathrm{~m}$ ASL at Vif (see Fig. 11). At low altitudes $(400,800$ and $1900 \mathrm{~m}$ ASL) one can see huge variations due to the ozone chemical processes in the mixing layer while at higher altitudes ( $3200 \mathrm{~m}$ ASL) these variations disappear completely. Furthermore at the higher elevation we notice again the good agreement between the LIDAR and the model. Thus we considered the ozone concentration measured by DIAL at $3200 \mathrm{~m}$ ASL to be the ozone background reference value $\mathrm{O}_{3}$ (bkg).

The change in ozone $\Delta \mathrm{O}_{3}$, calculated by subtracting this ozone background value, is shown in the Fig. 12a at four different altitudes situated below the maximum PBL height ( $3200 \mathrm{~m}$ ASL). The negative values correspond to "ozone sinks" (i.e. titration and dry deposition) while the positive values are "ozone sources" (e.g. photochemical and transport). The sinks are prevailing at the ground (reaching up to $40 \mathrm{ppb}$ ) at night and morning time while starting at $800 \mathrm{~m}$ ASL these sinks are almost negligible. The positive values of $\Delta \mathrm{O}_{3}$, presented in Fig. 12b, allows for the observation of different polluted layers in the PBL. The ground layer at $\sim 400 \mathrm{~m}$ ASL (black curve) is reflecting the ozone budget at Vif characterized by three peaks corresponding to the daily pollution maxima $+10 \mathrm{ppb}$ on 25 and 26 July occurring in 
the late afternoon (15:00 to 18:00 LT). The second layer at $1000 \mathrm{~m}$ ASL (red curve) is more polluted $(+30 \mathrm{ppb})$ and is representative of the mixing layer (ML) concentration and for the higher elevation rural sites (e.g. St-Barthélémy). It represents the source of the residual layer at midnight with $+15 / 20 \mathrm{ppb}$ relative to the background. These higher concentrations are the result of the lack of either NO titration and/or deposition processes.

The third layer at $2000 \mathrm{~m}$ ASL (blue curve) reflects the behavior of the top of the residual layer indicating the increase in height and thus the progressive accumulation of ozone during the three days analyzed here. Due to the change of the metrological regime on 27 July there is an increase of $30 \mathrm{ppb}$ for the ozone maximum, which is the result of rapid transport and vertical mixing in the these three layers above Vif.

\section{Conclusions}

This work demonstrates the usefulness of coupling a regional photochemical numerical model with LIDAR measurements for studying the ozone plume dynamics over a complex topography region as Grenoble. The LIDAR measurements at $20 \mathrm{~km}$ south of Grenoble and the model results are in a good agreement with the aircraft data for ozone concentration and PBL height estimation. The time evolution of the 3D ozone distribution, the ozone fluxes and the PBL height and its sublayers structure were identified for a typical summer photochemistry episode. The diurnal cycle of the thermal winds is the driving force for the ozone fluxes into the valley, in particular, bringing the ozone plume in the late afternoon at south of Grenoble up to $95 \mathrm{ppb}$. Both model predictions and LIDAR measurements show high values of the PBL height up to $2700 \mathrm{~m}$ above ground surface in daytime. An important and persistent residual ozone layer with concentrations of $60-70 \mathrm{ppb}$ is identified between 1300 and $2300 \mathrm{~m}$ above the ground. Finally treating the free troposphere ozone as a reference (background), which is independent of the regional photochemistry, we deduced the potential of the ozone production by Grenoble city at about $30 \mathrm{ppb}$ of ozone as well as the magnitude of NO titration and deposition processes at about 30-40 ppb.

Acknowledgements. The authors kindly thanks ASCOPARG (ASsociation pour le COntrôle et le Préservation de la qualité de l'Air en Région Grenobloise) and the ADEME (Agence de l'Environnement et de la Maîtrise de l'Energie) for conducting and funding the project, the Vif authorities, B. Neininger from METAIR, the DEGREANE company, the Swiss National Foundation and the Swiss Federal Office for Education and Science for the financial support of the ozone mobile LIDAR developments. We gratefully acknowledge also the helpful comments of Prof. Marc Parlange.

\section{References}

Ba, M. and Traimany, A.: Transport routier et nuisances atmosphériques, des efforts à poursuivre, 2001.

Berthoux, P.: Wind Profiler Radar, type PCL1300 Presentation and Utilisation Manual, DEGREANE, Toulon, France, 1999.

Beyrich, F., K. Acker, K., Kalab, D., Klemm, O., Moller, D., Schaller, E., Werhahn, J., and Weisensee, U.: Boundary layer structure and photochemical pollution in the Harz Mountains an observational study, Atmospheric Environment, 30 (8), 12711281, 1996.

Calpini, B., Simeonov, V., Jeanneret, F., Kuebler, J., Sathya, V., and Van den Bergh, H.: Ozone LIDAR as an Analytical Tool in Effective Air Pollution Management: The Geneva 96 Campaign, Chimia, 51, 700-704, 1997.

Couach, O., Balin, I., Jiménez, R., Perego, S., Kirchner, F., Ristori, P., Simeonov, V., Quaglia, P., Vestri, V., Clappier, A., Calpini, B., and Van den Bergh, H.: Study of a photochemical episode over the Grenoble area using a mesoscale model and intensive measurements, Pollution Atmosphrique, 174, 2002a.

Couach, O., Balin, I., Jiménez, R., Quaglia, P., Kirchner, F., Ristori, P., Simeonov, V., Clappier, A., and Calpini, B.: Measurements and modeling of the air pollution and the meteorology on a complex topography region: case study Grenoble 1999, in European Geophysical Society, Nice, France, 2002b.

Couach, O., Balin, I., Quaglia, P., Jiménez, R., Simeonov, V., Larchevêque, G., Lazzarotto, B., Kuebler, J., Sathya, V., Martilli, A., Junier, M., Roulet, Y. A., Kirchner, F., Clappier, A., Calpini, B., and Van den Bergh, H.: Campagne de mesures intensives 1999 sur la région grenobloise, ensemble des rsultats et analyse des Périodes d'Observations Intensives (POI), LPAS-EPFL, Lausanne, 2000.

Couach, O., Besson, C., Kuebler, J., Martilli, A., Sathya, V., Larchevêque, G., Clappier, A., Calpini, B., and Van den Bergh, H.: Campagne de mesures 1998 de la pollution de l'air sur la région grenobloise, LPAS-EPFL, Lausanne, 1999.

Haagen-Smit, A. J., Bradley, C. E., and Fox, M. M.: Ozone formation in photochemical oxidation of organic substances, Ind. Ing. Chem., 45, 2086-2089, 1953.

Jiménez, R., Martilli, A., Balin, I., Van den Bergh, H., Calpini, B., Larsen, B., Favaro, G., and Kita, D.: Measurement of formaldehyde (HCHO) by DOAS: Intercomparison to DNPH measurements and interpretation from Eulerian model calculations, Proceedings of A\&WMA 93rd Annual Conference, Salt Lake City (UT), Paper \# 829, 2000.

Jiménez, R., Simeonov, V., Couach, O., Van den Bergh, H., and Calpini, B.: Development and application of UV-visible and mid-infrared differential absorption spectroscopy techniques at the Swiss Federal Institute of Technology - Lausanne (EPFL), in DOAS Workshop 2001 - New Developments and Applications, Institute of Environmental Physics (IUP), Heidelberg (Germany), 2001.

Majewski, D.: The Europa Modell of the Wetterdienst, ECMWF Seminar on numerical methods in atmospheric models, 2, 147191, 1991.

McKendry, I. G., Steyn, D. G., Lundgren, J., Hoff, R. M., Strapp, W., Anlauf, K., Froude, F., Martin, J. B., Banta, R. M., and Olivier, L. D.: Elevated ozone layers and vertical down-mixing over the lower fraser valley, BC, Atmos. Env., 31 (14), 21352146, 1997. 
Menut, L., Flamant, C., Pelon, J., and Flamant, P. H.: Urban boundary layer height determination from lidar measurements over the Paris area, Applied Optics, 38, 945-954, 1999.

Neininger, B., Fuchs, W., and Baeumle, M.: A small aircraft for more than just ozone: Metair Dimona after ten years of evolving development, in 11th Symposium on Meteorological Observations and Instrumentation, 81st AMS Anual Meeting, Albuuquerque USA, 2001.

Neu, U., Künzle, T., and Wanner, H.: On the relation between ozone storage in the residual layer and daily variations near surface ozone concentrations - a case study, Boun.-Layer Meteor., 69, 221-247, 1994.

Parlange, M. B., Eichinger, W., and Albertson, J. D.: Regional scale evaportaion and the atmospheric boundary layer, Reviews of Geophysics, 33 (1), 99-124, 1995.

Perego, S.: Metphomod - a numerical mesoscale model for simulation of regional photosmog in complex terrain: model description and application during Pollumet 1993 (Switzerland), Meteorol. Atmos. Phys (70), 43-69, 1999.

Prévôt, A. S. H., Dommen, J., Bäumle, M., and Furger, M.: Diurnal variations of volatile organic compounds and local circulation systems in an alpine valley, Atmos. Env., 34, 1413-1423, 2000.

Quaglia, P., Larchevèque, G., Simeonov, V., Lazzarotto, B., Ancel- let, G., Van den Bergh, H., and Calpini, B.: Planetary boundary layer ozone fluxes from combined airborne, ground based LIDARs and Wind profilers measurements, Eur. J. of An. Chem. (Analusis), 27 (4), 305-310, 1999.

Ruffieux, D.: Use of a Wind Profiler in Planetary Boundary Layer Experiment, Eur. J. of An. Chem. (Analusis), 27 (4), 310-312, 1999.

Russel, A. G. and Denis, R.: NARSTO critical review of photochemical models and modelling, Atmos. Env., 34, 2283-2324, 2000.

Simeonov, V., Larchevèque, G., Quaglia, P., Van den Bergh, H., and Calpini, B.: The influence of the PMT spatial uniformity on LIDAR signal, App. Opt, 38 (24), 5186-5190, 1999a.

Simeonov, V., Lazzarotto, B., Larchevêque, G., Quaglia, P., and Calpini, B.: UV ozone DIAL based on Raman cell filled with two Raman active gases, in Proceeding of Enviroscience 1999, Munich Germany, 1999b.

Stockwell, W. R., Kirchner, F., Kuhn, M., and Seefeld, S.: A new mechanism for regional atmospheric chemistry modeling, J. Geophys. Res., 102(D22), 25 847-25 879, 1997.

Wotawa, G. and Kromp-Koft, E.: The research project VOTALP general objectives and main results, Atmos. Env., 34, 1319-1322, 1999. 